\title{
Kaitan Pembelajaran Bahasa Indonesia dengan Lingkungan
}

Oleh Ulfa Fauziyah.M

ulfafauziyah89@gmail.com

Dalam melakukan komunikasi diperlukannya suatu bahasa. Dalam penerapannya, bahasa memiliki peranan penting dalam kehidupan manusia. Sebab, perilaku manusia dan budaya suatu bangsa dapat terlihat dari bahasa yang digunakan. Bahasa Indonesia memiliki kedudukan yang tinggi, karena bahasa Indonesia merupakan bahasa resmi bangsa Indonesia. Untuk itu, pengaplikasian bahasa Indonesia dapat diajarkan sejak dini dari lingkungannya, baik itu lingkungan formal maupun informal guna menanamkan nilai-nilai kehidupan dan sosial sejak dini.

Pembelajaran bahasa Indonesia berkaitan erat dengan kondisi lingkungan sekitarnya. Lingkungan memiliki pengaruh yang besar dalam perkembangan bahasa anak. Dalam bentuk formal, materi lingkungan dapat dimasukkan ke dalam pembelajaran bahasa Indonesia di sekolah. Guru bisa mengaitkan antara teks-teks yang ada dalam pembelajaran bahasa Indonesia dengan contoh lingkungan. Pengenalan pendidikan lingkungan penting untuk dimasukkan dalam pembelajaran guna menumbuhkan kesadaran peserta didik dalam menjaga lingkungan sekitar. Hal ini juga sesuai dengan Ramadhan et.al (2019) yang mengatakan bahwa pendidikan lingkungan penting untuk meningkatkan sikap dan kesadaran peserta didik terhadap lingkungan hidup. Pendidikan lingkungan dapat membuat siswa berfikir secara kritis dan kontekstual. Cara berfikir yang kritis dan kontekstual ini berpengaruh nantinya terhadap pembelajaran bahasa Indonesia, sehingga antara pendidikan lingkungan dan pembelajaran bahasa saling berkaitan. Sukma (2005) pemakaian bahasa berkaitan erat dengan hubungan sosial antarpenutur yang berada di tengah-tengah masyarakat.

Menurut Ramadhan et.al (2018) model pembelajaran yang inovatif mampu meningkatkan hasil belajar peserta didik. Maka dari itu, pengintegrasian pendidikan lingkungan dalam proses pembelajaran bahasa Indonesia merupakan salah satu cara dalam mewujudkan dan mengembangkan kemampuan siswa sehingga siswa dapat berinovasi dan berkolaborasi dengan lingkungan yang ada disekitar mereka. Dilanjutkan kembali, menurut Ramadhan et.al (2019) lembaga pendidikan sebagai pemangku kepentingan utama wajib meningkatkan kesadaran lingkungan siswa. Di Indonesia, pendidikan lingkungan bukanlah pelajaran yang wajib di sekolah. Oleh karena itu, pendidikan berbasis lingkungan dapat diterapkan dalam mata pelajaran lain, seperti mata pelajaran bahasa Indonesia. Ramadhan 
et.al (2019) mengungkapkan bahwa penggunaan tema lingkungan dalam pembelajaran yang berbasis teks dapat memicu minat siswa belajar bahasa dan secara implisit mampu meningkatkan pengetahuan siswa mengenai lingkungan.

Sukma (2017) kemampuan dalam berliterasi memiliki pengaruh yang signifikan terhadap keberhasilan siswa dalam belajar dan kehidupan sehari-hari. Melalui keterampilan literasi yang baik, akan membantu siswa dalam memahami teks lisan, tulisan, dan teks visual. Sukma (2019) guru hendaknya memberikan motivasi kepada siswa. Melalui motivasi tersebut seorang guru dapat menciptakan berbagai pengalaman belajar bagi siswa. Indriyani et.al (2019) literasi siswa perlu ditingkatkan terutama literasi baca tulis. Kemudian, juga perlu mengetahui bagaimana pelaksanaan literasi yang telah dilaksanakan di sekolah. Sukma (2020) penanaman karakter penting ditanamkan sejak siswa masih duduk dibangku sekolah dasar. Penanaman karakter dapat dilakukan dalam proses pembelajaran di sekolah. Banyaknya keragaman karakter dan kebiasaan siswa di sekolah berasal dari latar belakang keluarga yang berbeda merupakan pengaruh besar sehingga menimbulkan hal-hal buruk dari karakter anak yang buruk.

Hartidini et.al (2018) literasi merupakan jantung dari kemampuan siswa untuk berhasil dalam pembelajarannya di sekolah dan juga untuk menghadapi berbagai tantangan pada masa mendatang. Kualitas pembelajaran bahasa Indonesia di ligkungan sekolah dipengaruhi dengan metode belajar yang diterapkan oleh guru, dan minat siswa dalam pembelajaran. Putri dan Syahrul (2019) mengungkapkan bahwa dalam pembelajaran di lingkungan sekolah, pengajaran membaca harus memperoleh perhatian yang serius dari pendidik di Indonesia. Melalui pengajaran, pendidik mampu mengarahkan peserta didik dalam pembelajaran bahasa. Sari et.al (2018) membaca secara komunikatif digunakan untuk mencari, menemukan, dan memperoleh informasi dari berbagai sumber sesuai dengan oemahaman masing-masing individu yang diperoleh.

Maka dari itu, perlu dilakukan penyebaran angket guna mengetahui tingkat persentase hubungan atau keterkaitan antara pembelajaran bahasa Indonesia dengan lingkungan sosial siswa. Penyebaran angket ini bertujuan untuk mengetahui tingkatan dari empat opsi dari hasil pernyataan yang telah disajikan dengan respondennya berupa siswa kelas VIII SMP Negeri 2 Pariaman, mahasiswa UNP semester 5, UIN Imam Bonjol Padang semester 5, IAIN Batusangkar semester 5, STIT SB Pariaman semester 5, UIN Sunan Kalijaga semester 5, Ma'had Azzubair bin Al-awam semester 5, dan guru SMAN 1 V Koto Kp.Dalam. Secara keseluruhan responden berjumlah 30 orang. Hasil data dari persentase angket yang telah dilakukan melalui google form tersebut dapat dilihat sebagai berikut. 
Pernyataan pertama, pengenalan lingkungan sangat berpengaruh terhadap pembelajaran bahasa Indonesia, persentasenya menunjukkan $70 \%$ setuju dan $30 \%$ sangat setuju. Pernyataan kedua, pembelajaran bahasa Indonesia memiliki peranan penting untuk mengembangkan pengetahuan tentang lingkungan, kesadaran lingkungan, dan perubahan perilaku terhadap lingkungan, presentase yang diperoleh dari angket yaitu 53,3\% menyatakan setuju dan 43,3\% menyatakan sangat setuju. Pernyataan ketiga, lingkungan dijadikan sebagai sumber inspirasi untuk membangun kecerdasan kebahasaan, presentasenya 53,3\% menyatakan setuju dan $43,3 \%$ kurang setuju. Pernyataan keempat, pembelajaran berbasis lingkungan bertujuan untuk membuat siswa berpartisipasi dalam menjaga dan melindungi sekitar, presentase yang diperoleh yaitu $56,7 \%$ menyatakan setuju, dan $40 \%$ menyatakan sangat setuju. Kemudian pernyataan kelima, dalam pembelajaran bahasa Indonesia guru harus menggunakan teks-teks yang bertemakan lingkungan, presentase yang diperoleh yaitu $53,3 \%$ menyatakan setuju, 23,3\% yang menyatakan kurang setuju, dan $20 \%$ menyatakan setuju. Pernyataan keenam, salah satu cara untuk menciptakan suasana belajar yang kondusif dapat dilakukan dengan memanfaatkan lingkungan sekitar guna mengembangkan aktivitas dan kreatifitas belajar secara optimal, presentase dari pernyataan ini dari hasil angket yaitu $56,7 \%$ menyatakan setuju, dan $43,3 \%$ menyatakan sangat setuju. Pernyataan ketujuh, kemampuan berbicara dan memahami bahasa dipengaruhi oleh faktor lingkungan, persentasenya menunjukkan $56,7 \%$ setuju, dan $40 \%$ sangat setuju. Pernyataan kedelapan, guru memiliki peranan penting dalam mengenalkan pendidikan lingkungan melalui pembelajaran di kelas, persentasenya menunjukkan $60 \%$ yang menyatakan setuju, dan $40 \%$ yang menyatakan sangat setuju. Pernyataan kesembilan, dalam kaitannya antara pembelajaran bahasa Indonesia dengan lingkungan, siswa bisa mengamati apa saja yang ada di lingkungan sekitar. Kemudian menjadikan pengamatan tersebut sebagai salah satu sumber inspirasi untuk membuat salah satu karya sastra berupa teks laporan hasil observasi, persentasi dari pernyataan ini yaitu $70 \%$ menyatakan setuju, dan 26,7\% menyatakan sangat setuju. Pernyataan kesepuluh, pemanfaatan lingkungan belajar diharapkan mampu membantu proses perkembangan individu menjadi makhluk sosial yang dapat beradaptasi degan baik di lingkungannya, persentase dari pernyataan ini yaitu $60 \%$ menyatakan setuju dan $40 \%$ menyatakan sangat setuju.

Berdasarkan penjelasan di atas, dapat disimpulkan bahwa pendidikan lingkungan berkaitan erat dengan pembelajaran bahasa Indonesia. Sebab, melalui lingkungan, siswa mampu mengembangkan kemampuan ekologis, berpikir kreatif, inovatif, dan mampu meningkatkan kesadaran siswa pentingnya menjaga lingkungan 


\section{DAFTAR PUSTAKA}

Hartidini S, Syahrul R, dan Ellya R. (2018). Pengaruh Strategi Pembelajaran Inkuiri Berbantuan Media Audiovisual terhadap Keterampilan Menulis Karangan Argumentasi Siswa Kelas X SMA Negeri 2 Lengayang Kabupaten Pesisir Selatan. Jurnal Pendidikan Bahasa dan Sastra Indonesia, Vol.1 No.7, seri A63-69.

Putri D, dan Syahrul R. (2019). Korelasi Keterampilan Membaca Pemahaman dan Keterampilan Menulis Teks Laporan Hasil Observasi Siswa Kelas VII SMP Negeri 4 Pariaman. Jurnal Pendidikan Bahasa dan Sastra Indonesia, Vol. 8 No.1, seri 62-69.

Sukma E. (2005). Penerapan Pendekatan Komunikatif dalam Pembelajaran Struktur Bahasa Indonesia di Sekolah Dasar. Diksi, Vol.12 No.1.

Sukma E. et.al. (2019). Problems in Oral Language Teaching in Primary School. Advances in Social Science. Education and Humanities Research, Volume 301.

Sukma E, Ritawati M, dan Rizky A. (2017). Literacy Media Development in Improving Reading and Writing Skill of Early Class Students in Elementary School Padang Utara Padang. Advances in Social Science, Education and Humanities Research, Vol 118.

Sukma E, dan VP Azrianti. (2020). Instilling Positive Characters in Students Using Folker in the Macromedia Application. Advances in Social Science, Education and Humanities Research, Volume 485.

Ramadhan S, Asri Y, dan V Indriyani . (2018). Learning Module Design Writing Argumentative Text Based Problem-Based Learning. In Advances in Social Science:Education and Humanities Research, Vol 263:194-200.

Ramadhan S, Sukma E, dan V Indriyani. (2019). Environmental Education and Disaster Mitigation Through Languange Learning. IOP Conference Series: Earth and Environmental Science, 314.

Indriyani V, Zaim M., Atmazaki, dan Syahrul R. (2019). Literasi Baca Tulis dan Inovasi Kurikulum Bahasa. Kembara: Jurnal Keilmuan Bahasa, Sastra, dan Pengajarannya, Vol 5 (1):108-118.

Sari Y, Syahrul R, dan Yulianti R. (2018). Hubungan Antara Keterampilan Membaca Pemahaman dengan Keterampilan Menulis Teks Laporan Hasil Observasi Siswa Kelas X SMK Negeri 3 Padang. Jurnal Pendidikan Bahasa dan Sastra Indonesia, Vol.7, No.3; seri F446-453. 